Research Article

\title{
Ash Evaluation of Indonesian Coal Blending for Pulverized Coal-Fired Boilers
}

\author{
Hariana (D), ${ }^{1}$ Adi Prismantoko $\left(D,{ }^{1}\right.$ Ganda Arif Ahmadi, ${ }^{2}$ and Arif Darmawan (iD ${ }^{1}$ \\ ${ }^{1}$ National Research and Innovation Agency, Jakarta, Indonesia \\ ${ }^{2}$ PT Indonesia Power, Jakarta, Indonesia \\ Correspondence should be addressed to Hariana; hariana@bppt.go.id
}

Received 19 August 2021; Accepted 8 November 2021; Published 14 December 2021

Academic Editor: Benjamin Shaw

Copyright (c) 2021 Hariana et al. This is an open access article distributed under the Creative Commons Attribution License, which permits unrestricted use, distribution, and reproduction in any medium, provided the original work is properly cited.

Coal calorific value is one of the main considerations for using coal as a power plant fuel. In addition, the requirements for indications of slagging and fouling are also important to maintain combustion efficiency. However, coal power plants often experience problems in boiler operations due to the use of certain types of coal, even though they have a relatively high calorific value. This research investigates the effect of coal blending on ash fouling and slagging in an experimental investigation using a drop tube furnace with or without additives. Five different types of coal from different locations have been used in this study. Pulverized low-rank coal samples are burned in a drop tube furnace at $1,175^{\circ} \mathrm{C}$ with probe temperatures of $550^{\circ} \mathrm{C}$ and $600^{\circ} \mathrm{C}$, corresponding to the combustion chamber of $600 \mathrm{MW}$ power plants, including superheater and reheater areas. The ash particles' characteristics and material composition were also analyzed using scanning electron microscopy with energy-dispersive X-ray (SEM-EDX) and X-ray diffraction (XRD), respectively. All coal mixture combinations demonstrated potential as a fuel for power plants that use pulverized coal-fired boilers. Because of its capacity to reduce slagging and fouling potentials, combining coal blending with the use of chemical additives yielded the greatest results.

\section{Introduction}

Most of the power plants in Indonesia use fossil fuels, with coal as the largest contributor of about 60\% [1]. Large economic growth leads to higher electricity consumption in a straight line. Consequently, coal power plants have become one of the important national energy sectors. The country is also one of the largest coal exporters, with $20 \%$ of coal in the international market coming from Indonesia. In 2019, coal recorded the largest production record of 610 million tons, of which 458.8 million tons became export commodities. Low-rank coal (calorific value below $5,100 \mathrm{kcal} / \mathrm{kg}$ ) and medium-rank coal $(5,100-6,100 \mathrm{kcal} / \mathrm{kg})$ dominate current Indonesian coal production. Coal reserves are estimated to be about $38.45 \%$ for low-rank coal and around $54.11 \%$ for medium-rank coal. The country's power plants use both types of coal as fuel.

Basically, coal calorific value is one of the main considerations for using coal as a power plant fuel. In addition, the requirements for slagging and fouling measurements are also important to maintain sustainable combustion efficiency. As a solution, the coal combustion analysis tool can indicate the slagging and fouling effects of coal burned inside the boiler. Coal power plants often experience problems in boiler operations due to the use of certain types of coal, even though they have a relatively high calorific value [2]. Hare et al. [3] stated mixing the main coal with other coals can solve slagging and fouling problems. The effect of coal blending on the combustion performance of low-rank coals was also investigated [4]. The study found the coal blends could extend combustion operation by controlling particle agglomeration and bed defluidization. Another study also reported the effect of coal blending and ashing temperature on ash sintering and its characterization using lignite from China blended with Australian bituminous and Indonesian lignite, respectively, at various blending ratios [5-7]. Furthermore, Plaza [8] developed a tool to predict the effects of biomass cofiring with coal on pulverized fired boilers' ash 
deposition and thermal performance. In their work, Chuan et al. [6] investigated the influence factors of slagging and fouling using Zhundong coal and a Si/Al-dominated lowrank coal with various ratios. The results demonstrate that blending has a severe slagging and fouling tendency when the alkali/acid ratio is greater than 0.400 , and the difference between ST and DT (ST-DT) is less than $20^{\circ} \mathrm{C}$. Furthermore, the operating data of a commercial coal-fired boiler was extracted for six coal blends by Park et al. [9]. The investigation was conducted to determine the thermal resistance by slagging. They found the conventional slagging indices for the six ash samples did not match well with the thermal resistance of the slag. In general, coal blending optimization can improve the diversity of prepared coal, quality, and stability [10]. In addition, it can increase the calorific value of the blend while decreasing inorganic content. Karin [11] also conducted a full-scale experimental study to understand the basic knowledge about ash deposit formation and elucidate factors in three power plants. The results indicated that burning coals with medium slagging tendencies in an existing boiler could cause more issues in future boilers.

Adding additives is another method to overcome slagging and fouling problems. Antislagging additives have already been used for coal combustion, coal gasification, or biomass combustion. The additives are used to minimize slagging and fouling during these processes. For example, Lowe et al. [11] investigated the effectiveness of fuel additives at alleviating alkali bonded fouling on a laboratory and industrial scale. It was demonstrated that kaolinite could reduce alkali bonded fouling in stokers or FBC. Laboratory studies indicated that available sodium levels are reduced by a reaction between the kaolinite and sodium. Large-scale studies confirmed that this corresponded to reduced quantities of lower strength deposits when the kaolinite was premixed with the coal. Therefore, injection of kaolinite is less acceptable. Zhao et al. [12] performed a systematic study to examine the effectiveness of $\mathrm{MgO}$ based additives in mitigating fouling problems in $\mathrm{kraft}$ recovery boilers. They found the additive coating does not affect deposit accumulation. However, an air blow-off jet greatly facilitates the deposit removal if a coating thickness greater than $5 \mu \mathrm{m}$ can be applied on the tube surface. Mechanical mixing and separate injection of additive and black liquor have an insignificant effect on deposit accumulation and removal since the amount of $\mathrm{Mg}$ deposited on the probe is too small. Furthermore, additives with various chemical compositions and potential counteracting effects can reduce ash-related issues during biomass combustion. The most important effect of additions is chemical binding, which turns hazardous ash components into high-temperature stable compounds [13]. More studies are still needed for further understanding of the interactions between additives and biomass ashes. Critical studies are necessary to increase our understanding further. In the most recent studies, the fusion behavior of hydro char ash is shown to be improved using rice hulls and kaolin as aluminum-silicate-based additives [14]. Rice hulls with kaolin can raise the temperature of hydrochar ash fusion to around $1,500^{\circ} \mathrm{C}$. However, utilizing bentonite, lime, or combining lime with rice hulls, bentonite, or kaolin had less promising results. Yanqi et al. [15] analyzed the impact of additives on slagging and fouling in the Zhundong coal gasification process. Six additives were tested in a horizontal tube furnace to see if they may help reduce fouling and slagging during coal gasification. The additives included kaolin, boehmite, corundum, quartz, raw vermiculite, and ripe vermiculite.

However, although widely studied, almost no study deals with the effect of chemical additives during mixed fuel combustion on slagging and fouling behavior. This research is aimed to investigate the effect of coal blending on ash fouling and slagging in a pilot experiment using a drop tube furnace with or without additives. Three different types of coal from different locations have been used in this study. The ash particles' characteristics and material composition were also analyzed using scanning electron microscopy with energy-dispersive X-ray (SEM-EDX) and X-ray diffraction (XRD), respectively.

\section{Materials and Methods}

2.1. Materials and Preparation. The Indonesian coal samples were originated from East Kalimantan province (KT coal). In addition, SS coal from South Sumatra, KP coal from East Kalimantan, KS coal from South Kalimantan, and spot purchased coal (TK coal) were selected to prepare coal blends. The chemical composition of coal can be seen in Table 1 . The blended coal of KT (50\%) and SS (50\%) coal was then called BD-1A (without additives) and BD-1B (with additives). BD-2A is a mixture of $\mathrm{KT} 1$ (50\%) and $\mathrm{KP}(50 \%)$ coal without additives, while $\mathrm{BD}-2 \mathrm{~B}$ is a blend of $\mathrm{KT}(50 \%)$ and $\mathrm{KP}(50 \%)$ coal with additives. $\mathrm{BD}-3 \mathrm{~A}$ is $50 \% \mathrm{KT}$ and $50 \%$ TK coal blend without additives, and $\mathrm{BD}-3 \mathrm{~B}$ is $50 \% \mathrm{KT}$ and $50 \%$ TK coal blend with additives. The blended coal of KT (50\%) and KS (50\%) was called BD-4A (without additives) and BD-4B (with additives). For every 100 tons of coal, about $6 \mathrm{~kg}$ additives are added or $0.006 \%$. The coal material was prepared by crushing, which resulted in pulverized coal with $70 \%$ passing 200 mesh (75 microns) size of each coal. The pulverized fuel was then analyzed and blended according to the provisions, including additives $(\mathrm{MgO})$. The following table shows the characteristic of each coal, including the mixed coal:

This study uses the main equipment, DTF (drop tube furnace), a furnace with a ceramic tube length of $1,200 \mathrm{~mm}$, and an inner diameter of $72 \mathrm{~mm}$, as shown in Figure 1. The cofiring process is conducted in a downward direction inside the tubular furnace. Fuel mixture particles were delivered at a rate of $50-100 \mathrm{gr} / \mathrm{h}$ through a feeder positioned on the top of DTF. A plate-shaped probe is inserted into the furnace to capture ash deposits, and the temperature is adjusted. Furthermore, the ashes are cooled down and collected using sheets of paper developed by the authors. Then, their compositions are analyzed using scanning electron microscopy with energy-dispersive X-ray (SEM-EDX) and $\mathrm{X}$-ray diffraction (XRD). The furnace operates at a combustion chamber temperature of $1,175^{\circ} \mathrm{C}$ with an excess of $5 \% \mathrm{O}_{2}$, probe temperatures of $550^{\circ} \mathrm{C}$ and $600^{\circ} \mathrm{C}$. It 
TABLE 1: Chemical composition of coal.

\begin{tabular}{|c|c|c|c|c|c|c|c|c|c|c|c|c|c|c|}
\hline & & $\mathrm{KT}$ & SS & $\mathrm{KP}$ & TK & KS & $\mathrm{BD}-1 \mathrm{~A}$ & BD-1B & BD-2A & $\mathrm{BD}-2 \mathrm{~B}$ & BD-3A & $\mathrm{BD}-3 \mathrm{~B}$ & $\mathrm{BD}-4 \mathrm{~A}$ & $\mathrm{BD}-4 \mathrm{~B}$ \\
\hline Total ash & $\mathrm{adb}$ & 5.24 & 7.36 & 6.14 & 6.43 & 2.18 & 6.30 & 6.30 & 5.69 & 5.69 & 5.84 & 5.84 & 3.71 & 3.71 \\
\hline Total sulfur & $\mathrm{adb}$ & 0.71 & 0.36 & 0.50 & 0.20 & 0.13 & 0.54 & 0.54 & 0.61 & 0.61 & 0.46 & 0.46 & 0.42 & 0.42 \\
\hline Gross energy & $\mathrm{Ar}$ & 5,256 & 4,889 & 5,229 & 4,198 & 4,923 & 5,073 & 5,073 & 5,243 & 5,243 & 4,727 & 4,727 & 5,090 & 5,090 \\
\hline \multirow{4}{*}{ AFT red } & Deformation & 1,130 & 1,200 & 1,160 & 1,120 & 1,160 & 1,120 & 1,180 & 1,100 & 1,110 & 1,140 & 1,130 & 1,1 & 1,110 \\
\hline & Spherical & 1,140 & 1,300 & 1,170 & 1,130 & 1,170 & 1,210 & 1,220 & 1,110 & 1,120 & 1,160 & 1,140 & 1,150 & 1,120 \\
\hline & Hemisphere & 1,160 & 1,320 & 1,220 & 1,160 & 1,200 & 1,230 & 1,250 & 1,120 & 1,160 & 1,180 & 1,180 & 1,160 & 1,140 \\
\hline & Flow & 1,200 & 1,340 & 1,240 & 1,180 & 1,220 & 1,260 & 1,280 & 1,160 & 1,200 & 1,200 & 1,200 & 1,170 & 1,180 \\
\hline \multirow{4}{*}{ AFT oxy } & Deformation & 1,160 & 1,220 & 1,230 & 1,230 & 1,220 & 1,180 & 1,200 & 1,140 & 1,140 & 1,180 & 1,200 & 1,150 & 1,140 \\
\hline & Spherical & 1,170 & 1,330 & 1,250 & 1,250 & 1,250 & 1,230 & 1,260 & 1,160 & 1,200 & 1,230 & 1,240 & 1,180 & 1,190 \\
\hline & Hemisphere & 1,180 & 1,340 & 1,280 & 1,260 & 1,260 & 1,260 & 1,280 & 1,180 & 1,240 & & & & 1,240 \\
\hline & Flow & 1,320 & 1,400 & 1,300 & 1,300 & 1,300 & 1,280 & 1,300 & 1,220 & 1,260 & 1,260 & 1,260 & & 1,260 \\
\hline \multirow{11}{*}{ Ash composition } & & 44.97 & 68.78 & 52.74 & 35.83 & 33.32 & & & & & & & & 45.10 \\
\hline & $\mathrm{Al}_{2} \mathrm{O}_{3}$ & 12.84 & 16.03 & 20.19 & 18.24 & 12.00 & 14.44 & 20.78 & 16.52 & 16.74 & 15.54 & 18.34 & 12.42 & 15.78 \\
\hline & $\mathrm{Fe}_{2} \mathrm{O}_{3}$ & 9.04 & 3.36 & 7.35 & 14.02 & 13.95 & 6.20 & 7.05 & 8.20 & 9.86 & 11.53 & 11.91 & 11.50 & 9.84 \\
\hline & $\mathrm{CaO}$ & 9.85 & 3.14 & 5.19 & 18.65 & 16.25 & 6.50 & 5.08 & 7.52 & 9.12 & 14.25 & 11.52 & 13.05 & 10.4 \\
\hline & $\mathrm{MgO}$ & 3.20 & 1.46 & 3.44 & 4.64 & 10.10 & 2.33 & 2.38 & 3.32 & 3.41 & 3.92 & 2.66 & 6.65 & 4.12 \\
\hline & $\mathrm{TiO}_{2}$ & 0.45 & 0.48 & 0.64 & 0.63 & 0.66 & 0.465 & 0.61 & 0.55 & 0.58 & 0.54 & 0.65 & 0.56 & 0.64 \\
\hline & $\mathrm{Na}_{2} \mathrm{O}$ & 4.29 & 3.36 & 2.83 & 0.50 & 2.99 & 3.83 & 4.18 & 3.56 & 3.82 & 2.40 & 2.10 & 3.64 & 3.50 \\
\hline & $\mathrm{K}_{2} \mathrm{O}$ & 0.99 & 0.59 & 2.04 & 0.62 & 0.86 & 0.79 & 0.97 & 1.52 & 1.31 & 0.81 & 0.86 & 0.93 & 1.30 \\
\hline & $\mathrm{Mn}_{3} \mathrm{O}_{4}$ & 0.066 & 0.058 & 0.042 & 0.348 & 0.176 & 0.062 & 0.064 & 0.054 & 0.057 & 0.207 & 0.345 & 0.121 & 0.071 \\
\hline & $\mathrm{P}_{2} \mathrm{O}_{5}$ & 0.216 & 0.222 & 0.292 & 0.085 & 0.144 & 0.219 & 0.596 & 0.254 & 0.364 & 0.151 & 0.198 & 0.180 & 0.394 \\
\hline & $\mathrm{SO}_{3}$ & 13.85 & 2.28 & 5.02 & 6.22 & 9.35 & 8.07 & 6.42 & 9.44 & 9.20 & 10.04 & 7.50 & 11.60 & 8.68 \\
\hline
\end{tabular}

corresponds to the combustion chamber of $600 \mathrm{MW}$ power plants, including superheater and reheater areas.

Furthermore, the probe results were compared with Jones index; the coal ash attached to the probe was observed with an SEM JEOL JSM 6510-LA scanning electron microscope with MOXTEK 550i thin-film-coated IXRF energy-dispersive spectrometer. Scanning electron microscopy was tested using energy-dispersive X-ray spectroscopy (SEM-EDX) equipment, a technique for analyzing the elements near the surface of the selected microscopic region of the sample. Energydispersive detectors are used to measure the scattered X-ray, identifying characteristics of the elements. X-ray diffraction (XRD) analysis was performed using the EMPYREAN type Bragg-Brentano diffractometer from PANALYTICAL. Ash samples were analyzed using this equipment with a measurement angle of 15-80 degrees, measurement time per step of 1 second, X-ray material in $\mathrm{Cu}$, voltage $40 \mathrm{kV}$, and current $30 \mathrm{~mA}$. The mineral phase of the deposit was identified using HighScore Plus software v.3.0e. In addition, the characteristic peak intensity for each mineral was recorded and used to indicate the content of the mineral phase in the ash. Measurements on the ash samples were repeated three times, and it was found that the error was relatively high for each mineral phase at $15 \%$. High intensity represents the high content of this mineral phase in the ash, and vice versa.

2.2. Empirical Prediction of Ash Deposition. Fuel composition, boiler structure, and operating conditions affect ash deposition [16]. Many chemical and physical mechanisms that contribute to ash generation and deposition are well understood $[23,24]$. This knowledge has aided many utilities in reducing ash deposition problems in utility boilers. The ability to estimate the fuel's tendency to foul and slag is required to design and operate coal-fired boilers. The use of standardized ashing processes, ash fusion experiments, and some empirically based slagging and fouling indices has been the traditional method of predicting coal ash behavior $[8,23]$. Commonly, three models have been used, including models based on ash chemistry indices, thermochemical equilibrium models, and comprehensive combustion and ash formation/deposition models. Below, some of the most common coal ash chemistry indices used to predict ash deposition propensities are introduced [17].

2.2.1. Base-to-Acid Ratio. The base-to-acid ratio $(B / A)$ is defined as the ratio of basic oxides to acidic oxides as follows:

$$
\frac{B}{A}=\frac{\% \mathrm{Fe}_{2} \mathrm{O}_{3}+\% \mathrm{CaO}+\% \mathrm{MgO}+\% \mathrm{Na}_{2} \mathrm{O}+\% \mathrm{~K}_{2} \mathrm{O}}{\% \mathrm{SiO}_{2}+\% \mathrm{AI}_{2} \mathrm{O}_{3}+\% \mathrm{TiO}_{2}},
$$

where $\% \mathrm{Fe}_{2} \mathrm{O}_{3}$ is the weight percentage of $\mathrm{Fe}_{2} \mathrm{O}_{3}$ on an ash basis. The base-to-acid ratio should not be a single criterion for measuring ash deposition propensity, especially if it is less than 0.1 or greater than 1.0. The ratio has been linked to viscosities and ash fusion temperatures. It represents an ash's melting potential. The base-to-acid ratio in the range of 0.4 to 0.7 for most ashes implies low ash fusibility temperatures and thus a higher slagging potential.

2.2.2. Slagging Factor. The slagging factor, $R_{s}$, is an empirical parameter developed to relate ash analysis to fused slag deposits formed on furnace walls and other surfaces exposed primarily to radiant heat as follows:

$$
R_{s}=\frac{B}{A} X \% S(\text { coal } \mathrm{db}),
$$




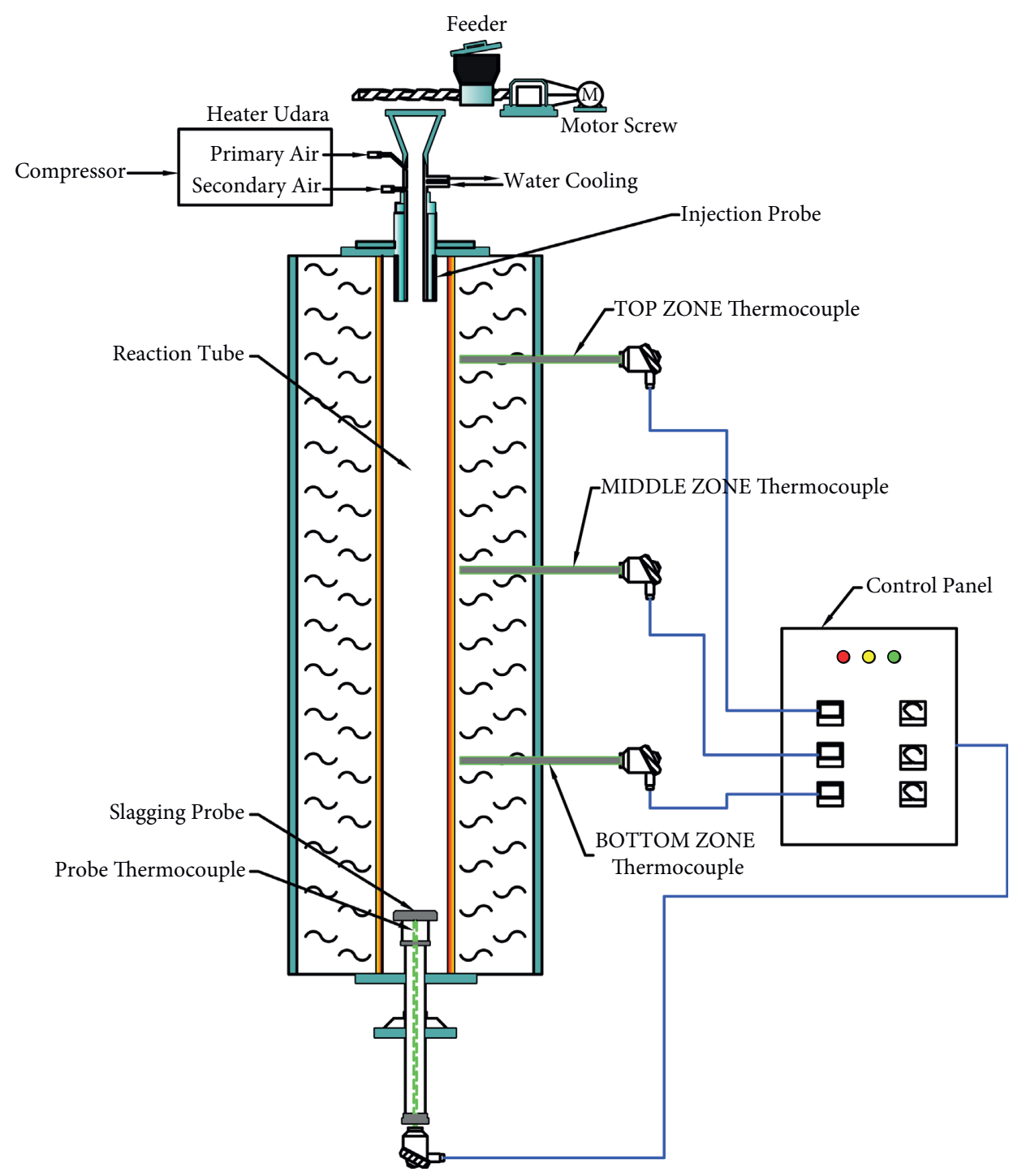

Figure 1: The schematic drawing of the drop tube furnace (DTF).

where $(B / A)$ is the base-to-acid ratio and $\% S$ is the sulfur content on a coal dry basis. The base-to-acid ratio indicates the melting point and viscosity of the slag. At the same time, $\% S$ indicates the quantity of pyritic iron present, which influences the oxidation state of iron in the slag (and thus the rheology of the slag) $[17,18]$. The recommended values for the evaluation of the slagging propensity of coal ash are as follows:

$$
\begin{aligned}
& R_{s}<0.6: \text { low } \\
& 0.6<R_{s} \leq 2.0: \text { medium } \\
& 2.0<R_{s} \leq 2.6: \text { high } \\
& R_{s}>2.6: \text { very high/severe }
\end{aligned}
$$

\subsubsection{Fouling Factor, Ash Fusibility Factor, and Silica Ratio.} The calculation of the ash fouling factor for bituminous ash coal is as follows:

$$
R_{f}=\frac{B}{A} \cdot\left(\% \text { water }- \text { soluble } \mathrm{Na}_{2} \mathrm{O}\right),
$$

where $R_{f}$ is an empirical parameter developed to predict the propensity of alkali bonded deposits to form on convection tube banks, especially superheaters and reheaters, which are not exposed to radiant heat from the furnace. Furthermore, during high-temperature thermal conversion processes, ash fusibility can indicate ash agglomeration and clinkering. In terms of representative fusion temperature, this parameter is estimated as follows:

$$
T_{\mathrm{AFI}}=\frac{4 I T+H T}{5} .
$$

The silica ratio $\left(S_{R}\right)$ is defined as follows:

$$
S_{R}=\frac{\% \mathrm{SiO}_{2}}{\mathrm{SiO}_{2}+\mathrm{Fe}_{2} \mathrm{O}_{3}+\mathrm{CaO}+\mathrm{MgO}} \times 100
$$


The recommended values for evaluating the fouling factor, ash fusibility factor, and silica ratio are provided in Table 2.

For lignite ash coal, the fouling factor is based on sodium $\left(\mathrm{Na}_{2} \mathrm{O}\right)$ content with the following calculation, if $\% \mathrm{CaO}+\%$ $\mathrm{MgO}+\% \mathrm{Fe}_{2} \mathrm{O}_{3}>20 \%$ wt coal ash, then the classification is as follows:

$$
\begin{aligned}
& \mathrm{Na}_{2} \mathrm{O}<3.0 \text { : low to medium } \\
& 3.0<\mathrm{Na}_{2} \mathrm{O}<6.0 \text { : high } \\
& \mathrm{Na}_{2} \mathrm{O}>6.0 \text { : very high } \\
& \text { If } \% \mathrm{CaO}+\% \mathrm{MgO}+\% \mathrm{Fe}_{2} \mathrm{O}_{3}< \\
& \text { classification is as follows: } \\
& \mathrm{Na}_{2} \mathrm{O}<1.2 \text { : low to medium } \\
& 1.2<\mathrm{Na}_{2} \mathrm{O}<3.0 \text { : high } \\
& \mathrm{Na}_{2} \mathrm{O}>3.0 \text { : very high }
\end{aligned}
$$$$
\text { If } \% \mathrm{CaO}+\% \mathrm{MgO}+\% \mathrm{Fe}_{2} \mathrm{O}_{3}<20 \% \text { wt coal ash, then the }
$$

\section{Results and Discussion}

\subsection{Effect of Coal Blending}

3.1.1. Slagging Fouling Prediction. Numerous empirical indices of slagging and fouling tendency based on ash composition have been developed and frequently used. Prediction of slagging fouling of coal mixture based on the results of coal characterization analysis can be seen in Table 3. It is worth noting that when the coal blending was added to additives, the indices of the base-to-acid ratio, slagging factor, silica ratio, and ash fusibility factor were slightly decreased. One of the most commonly utilized indicators is the $(B / A)$ ratio. This ratio represents the melting potential of coal ash and has been demonstrated to correlate with a viscosity at high temperatures and ash fusion temperature. However, corroboration with additional indices or factors is required, especially if the value is less than 0.1 or greater than 1.0. Based on the $(B / A)$ ratio and confirmed by slagging index, it seems all blending coal has low slagging tendencies. The slagging factor can also be predicted using the ash fusibility temperatures, although it is only applicable to bituminous ash. The fouling index $\left(R_{f}\right)$ demonstrated that it was prone to fouling. Depending on the mechanism of occurrence in coal, sodium may be vaporized in the flame and subsequently condensed on heat transfer surfaces in a boiler's colder convective pass, generating alkali-matrix deposits and corrosion. As a result, sodium oxide content in the ash and the total alkali content on a coal dry basis have been utilized to assess potential fouling problems [17].

3.1.2. Observation of Probes. Observations were performed on the combustion process, including the probe condition before and after burning coal and material cleaning. The following is a probe that has been used to capture dust and slag on DTF with a combustion chamber temperature of around $1,175^{\circ} \mathrm{C}$; the first and second rows are the results of coal ash on the probe with a temperature of $550^{\circ} \mathrm{C}$, which aims to describe the tube wall area, while the third and fourth rows are to describe the superheater region with a temperature of $600^{\circ} \mathrm{C}$. By comparing these probes, qualitative data can be obtained on how much ash adheres. Data were collected twice for each probe.

It can be seen in Table 4 that the material adheres at probe at a temperature of $600^{\circ} \mathrm{C}$ is generally more than that at $550^{\circ} \mathrm{C}$. It indicates that at higher temperatures, more elements have reacted or transformed. Moreover, the addition of $\mathrm{MgO}$ will have a positive effect because, due to the nature of $\mathrm{Mg}$, which makes the slag material brittle, it also inhibits melt production. However, it is necessary to conduct more in-depth research to determine the effect of adding this additive on the potential for slagging and fouling.

Table 5 shows the probes that have been cleaned of ash and lightly adhered slag. It can be seen that BD-1B and BD$4 \mathrm{~B}$ are the cleanest probes. Probes resulting from combustion with additives are generally cleaner than those without additives. Still, some probes show that the addition of additives affects the accumulation of slag, such as BD-2A. A review can also be done using the Jones index to predict the strength of the ash attached to the probe [19].

3.2. Observations with SEM. Evaluating the potential for slagging can be done by paying attention to morphology and elements (EDX). This morphological observation can be interpreted in the combustion conditions and material form.

3.2.1. $B D-1 A$ Probe at $550^{\circ} \mathrm{C}$ and $600^{\circ} \mathrm{C}$. At $100 \mathrm{x}$ magnification, it can be seen in Figure 2(a); the material is dominated by white, gray, and dark flakes at $500^{\circ} \mathrm{C}$. The predominant particle size is 100 microns. There are balls in small numbers in spot 1 in the form of balls with $52.75 \% \mathrm{Fe}$ as dominant element and other minor elements, but if we look at the morphology of this material, it is relatively not much. In spot 2, the main elements are $\mathrm{Si}$ and $\mathrm{Al}$; there are $1.33 \% \mathrm{Na}$ and $1.49 \% \mathrm{~K}$; others are relatively low. The material with typical spot 2 distribution is quite a lot. Although it is not dominant, the material with spot 3 is dominated by Si elements and a little Al. The distribution of chemical elements is the most dominant. The dominance at $1,000 \mathrm{x}$ magnification is $\mathrm{Si}$ and $\mathrm{Al}$; other elements are relatively low but still below $2 \%$. Overall, this $550^{\circ} \mathrm{C}$ probe is nothing to worry about.

At $600^{\circ} \mathrm{C}$, the predominance of the material at $100 \mathrm{x}$ magnification is the flakes, but there is a fine dust blanket around it in a small spherical shape (Figure 2(b)). There is a small amount of amorphous form dominated by dark colors and a little bright white. Spots 1 and 3 have similarities regarding the content of $\mathrm{Si}$ and $\mathrm{Al}$, with low $\mathrm{Fe}$. From the observation, these two types of material are dominant. Spot 2 is a material with an amorphous shape that is white, and the distribution is not dominant. The amount of $\mathrm{Al}$ and $\mathrm{Si}$ is about 27\%; other elements such as sulfur, $\mathrm{Ca}$, and $\mathrm{Fe}$ are about 3-5\%. 1,000x magnification details spot 2, where the $(\mathrm{Si}+\mathrm{Al})$ content is about $40 \%$. The $\mathrm{Fe}$ and $\mathrm{Ca}$ elements are in low amounts, but $\mathrm{Na}$ is enough to note, namely $1.99 \%$.

Under XRD analysis, as seen in Table 6, the BD-1A probe at $550^{\circ} \mathrm{C}$ is dominated by low quartz, $72 \%$, including similar minerals, namely silicon oxide $\mathrm{SiO}_{2}(2 \%)$. The quartz low 
TABLE 2: Recommended values for the evaluation of fouling factor, ash fusibility factor, and silica ratio.

\begin{tabular}{lccc}
\hline Fouling factor $\left(R_{f}\right)$ & Ash fusibility factor $\left(T_{A F I}\right)$ & Silica ratio $\left(S_{R}\right)$ & Criterion \\
\hline$<0.2$ & $>1,343$ & $>72$ & Low \\
$0.2-0.5$ & $1,232-1,343$ & $72 \geq S_{R}>65$ & Medium \\
$0.5-1$ & $1,149-1,232$ & $<65$ & High \\
$>1$ & $<1,149$ & - & Very high \\
\hline
\end{tabular}

TABLE 3: Slagging prediction of coal mixture combustion in DTF.

\begin{tabular}{ccccccccccc}
\hline No. & Index & BD-1A & BD-1B & BD-2A & BD-2B & BD-3A & BD-3B & BD-4A & BD-4B \\
\hline \multirow{2}{*}{1} & $(B / A)$ & 0.274 & 0.269 & 0.366 & 0.439 & 0.583 & 0.463 & 0.686 & 0.474 \\
& Criteria & Low & Low & Low & High & High & High & High & High \\
\hline \multirow{2}{*}{2} & $R_{s}$ & 0.16 & 0.16 & 0.25 & 0.30 & 0.30 & 0.24 & 0.33 & 0.23 \\
& Criteria & Low & Low & Low & Low & Low & Low & Low & Low \\
\hline \multirow{2}{*}{3} & $S_{R}$ & 79.10 & 78.06 & 71.96 & 66.96 & 57.63 & 62.66 & 55.65 & 64.93 \\
& Criteria & Low & Low & Low & Medium & High & Medium & High & High \\
\hline \multirow{2}{*}{4} & $T_{\text {AFI }}$ & 1,148 & 1,200 & 1,116 & 1,136 & 1,160 & 1,154 & 1,152 & 1,136 \\
& Criteria & Very high & High & Very high & Very high & High & High & High & Very high \\
\hline \multirow{2}{*}{5} & $R_{f}$ & 3.83 & 4.18 & 3.56 & 3.82 & 2.40 & 2.10 & 3.64 & 3.50 \\
& Criteria & Very high & Very high & Very high & High & Low & Low & High & High \\
\hline
\end{tabular}

TABle 4: Probe condition with dust and slag on DTF for each coal mixture with and without additives.

\begin{tabular}{lllllll}
\hline Probe temperatures $\left({ }^{\circ} \mathrm{C}\right)$ & $\mathrm{BD}-1 \mathrm{~A}$ & $\mathrm{BD}-1 \mathrm{~B}$ & $\mathrm{BD}-2 \mathrm{~A}$ & $\mathrm{BD}-2 \mathrm{~B}$ & $\mathrm{BD}-3 \mathrm{~A}$ & $\mathrm{BD}-3 \mathrm{~B}$ \\
\hline & & $\mathrm{BD}-4 \mathrm{~A}$
\end{tabular}

group of $74 \%$ is generally considered harmless. This number is medium and is a good trait. The $\mathrm{BD}-1 \mathrm{~A}$ probe at $600^{\circ} \mathrm{C}$ is dominated by high quartz, where $85 \%$ is generally considered harmless. In contrast, the other minerals are calcium sulfate $\left(\mathrm{CaSO}_{4}\right)$ as much as $15 \%$ either at $550^{\circ} \mathrm{C}$ or at $600^{\circ} \mathrm{C}$. $\mathrm{CaSO}_{4}$ that may occur is a reaction between $\mathrm{CaO}$ and $\mathrm{SO}_{2}$ or the elemental form of $\mathrm{CaSO}_{4}$ from the beginning. The reaction process occurs at temperatures between $800^{\circ} \mathrm{C}$ and $1,000^{\circ} \mathrm{C}$ in the gas phase. At $1,000^{\circ} \mathrm{C}-1,200^{\circ} \mathrm{C}$ and above temperatures, $\mathrm{SO}_{4}$ is released and can react with other elements such as $\mathrm{Si}$ or $\mathrm{Al}$ forming $\mathrm{Ca}_{2} \mathrm{Al}_{2} \mathrm{SiO}_{7}[20,21]$.

3.2.2. $\mathrm{BD}-1 \mathrm{~B}$ Probe at $550^{\circ} \mathrm{C}$ and $600^{\circ} \mathrm{C}$. Morphologically, the ash at $550^{\circ} \mathrm{C}$ probes at $100 \mathrm{x}$ magnification shows it is dominated by bright white flakes with a diagonal of about
100 microns, although some are larger than that (see Figure 3(a)). These bright white flakes indicate that $\mathrm{Si}$ and $\mathrm{Al}$ are influential here. There is also a grayish round shape that indicates Fe elements there, even in small amounts. Although not severe, some elements experience melting, possibly due to the presence of K. From the two enlargements above, the morphology and elements are within safe and reasonable limits. The thing to watch out for is the appearance of $\mathrm{K}$, where this element will melt at low temperatures and will bind $\mathrm{Si}$ or Al to form lumps that will melt at low temperatures. The presence of $\mathrm{Mg}$ in the ash will make the melt brittle (amorphous) so that it is easily overcome with a shoot blower.

The ash at $600^{\circ} \mathrm{C}$ (as seen in Figure 3(b)) is similar to the $550^{\circ} \mathrm{C}$ probe above, although it looks better. It indicates that the ash material appears to be dominated by flakes with 100 
TABLE 5: Probe condition after ash cleaning.

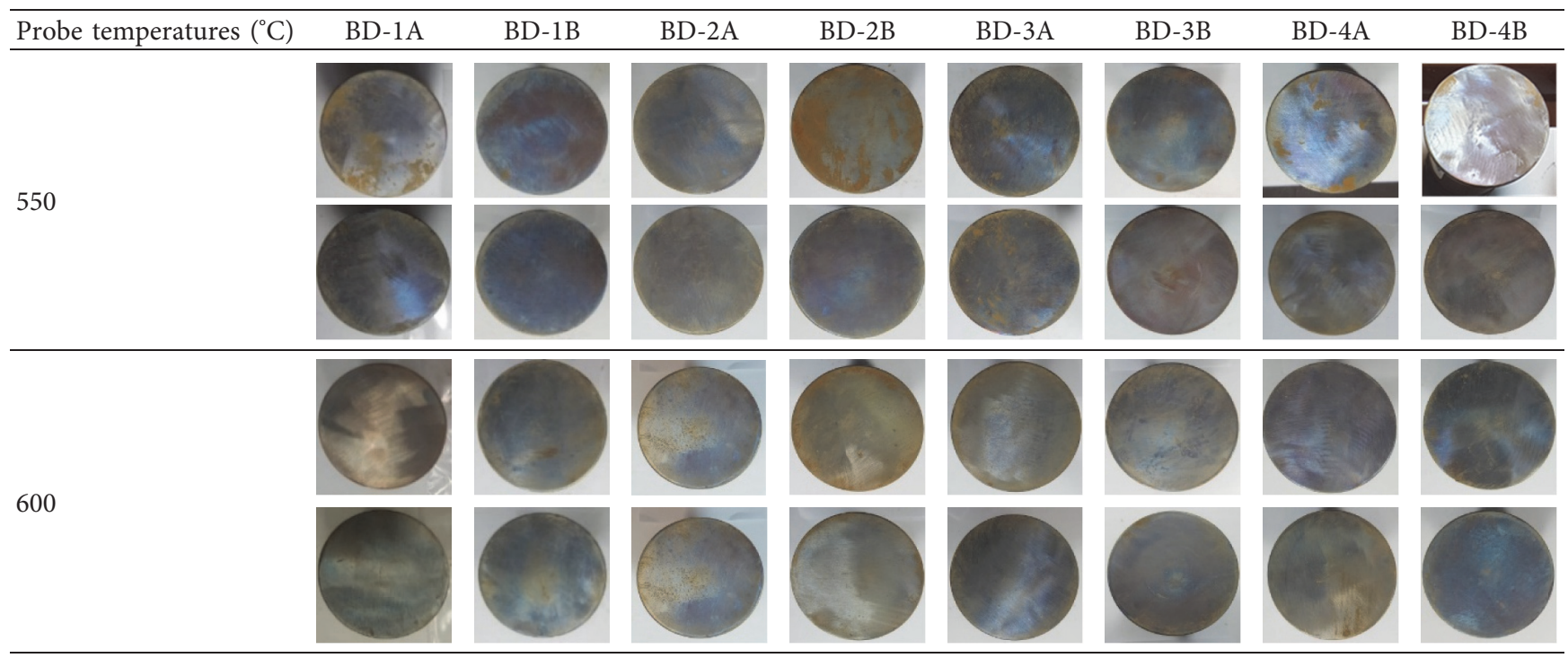
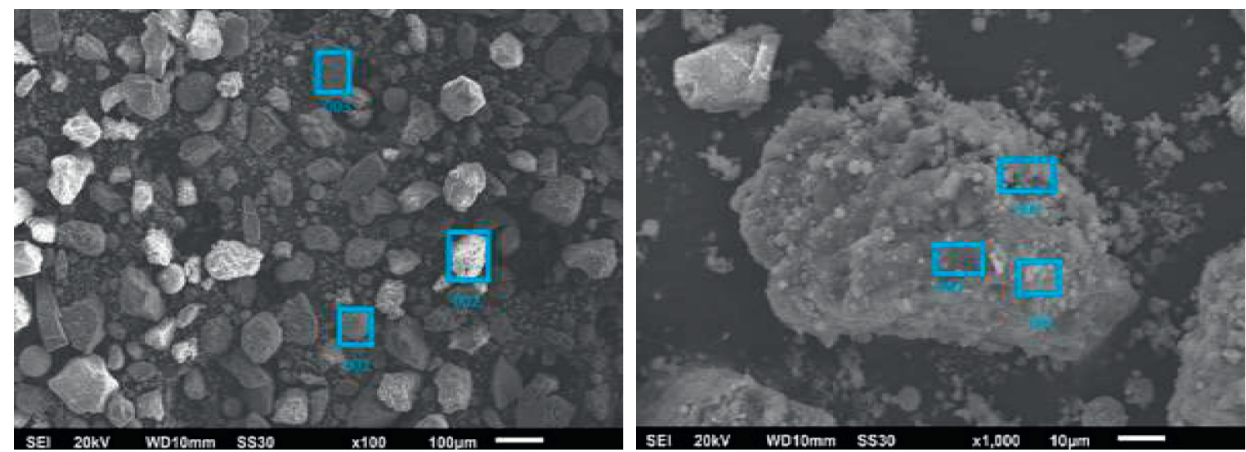

(a)
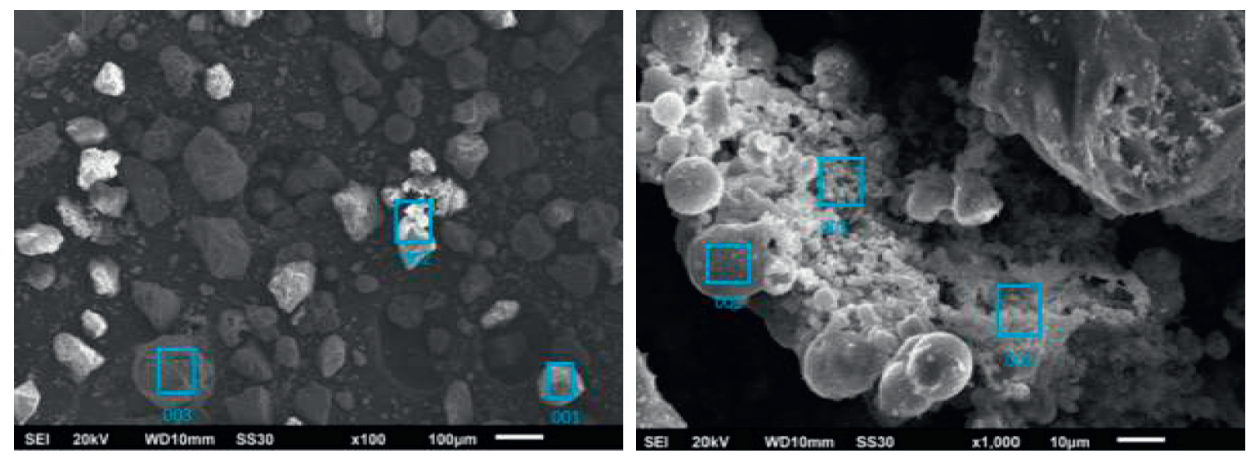

(b)

Figure 2: Comparison of 100x and 1,000x of BD-1A magnification at (a) $500^{\circ} \mathrm{C}$ and (b) $600^{\circ} \mathrm{C}$.

microns, with some appearing larger but some smaller. In terms of color, it appears a bright white color that indicates that $\mathrm{Si}$ and $\mathrm{Al}$ are quite even and abundant.

At 100x magnification, spot 1 is dominated by $\mathrm{Al}$ and $\mathrm{Si}$; the rest are elements of unburned carbon and oxygen. A similar condition is the third spot, but $\mathrm{Al}$ is lower with a darker color than spot 1. Ca appears with a high percentage of up to $21 \%$. At $1,000 \mathrm{x}$ magnification at the marked point, the dominance of $\mathrm{Si}$ is evident in the element list. In a reasonable amount, $\mathrm{Fe}$ and $\mathrm{K}$ are present. In terms of morphology and EDS of BD-1 coal using additives, we should consider further.

In XRD analysis, the material at $550^{\circ} \mathrm{C}$ is dominated by silicon oxide $\left(\mathrm{SiO}_{2}\right) 93 \%$, as depicted in Table 7. This element has harmless properties from its contribution to slagging and fouling and will even positively affect it. This element is stable until about $570^{\circ} \mathrm{C}$, where it will then transform into high quartz. At a temperature of $876^{\circ} \mathrm{C}$, it transforms into tridymite, and at a temperature of $1,400^{\circ} \mathrm{C}$, it transforms into cristobalite. Elemental quartz will be stable at a temperature 
TABLE 6: XRD analysis of BD-1A ash.

\begin{tabular}{lccc}
\hline Temp. $\left({ }^{\circ} \mathrm{C}\right)$ & Compound name & Chemical formula & SemiQuant $(\%)$ \\
\hline \multirow{2}{*}{550} & Quartz low & $\mathrm{O}_{2} \mathrm{Si}_{1}$ & 72 \\
& Calcium sulfate & $\mathrm{Ca}\left(\mathrm{SO}_{4}\right)$ & 15 \\
& Silicon oxide & $\mathrm{SiO}_{2}$ & 2 \\
& Chloride sulfur oxide & $\mathrm{SO}_{2} \mathrm{Cl}_{2}$ & 11 \\
\hline \multirow{2}{*}{600} & Quartz high & $\mathrm{O}_{2} \mathrm{Si}_{1}$ & 85 \\
& Calcium sulfate & $\mathrm{Ca}\left(\mathrm{SO}_{4}\right)$ & 15 \\
\hline
\end{tabular}
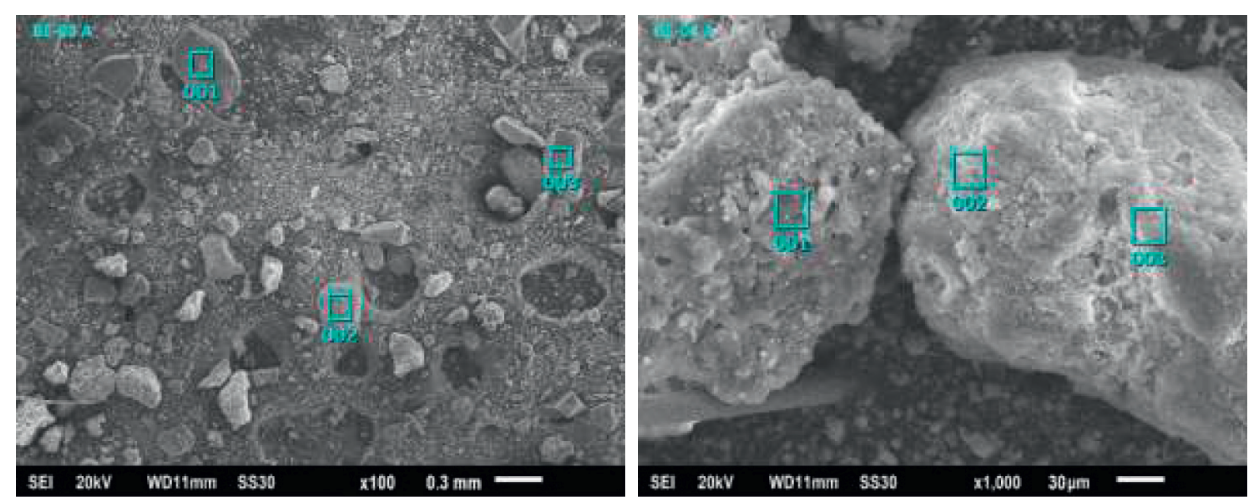

(a)
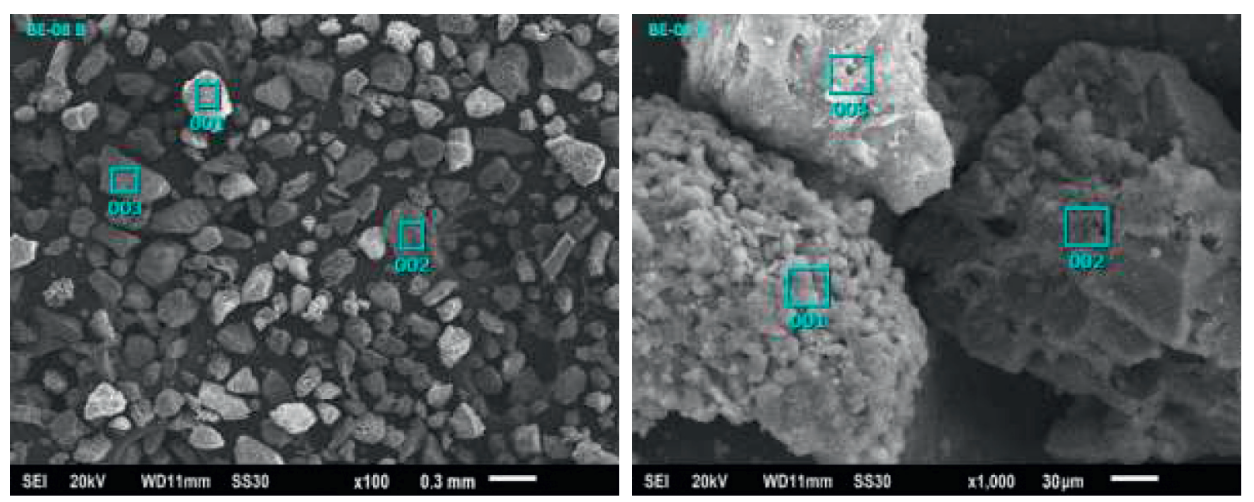

(b)

Figure 3: Comparison of 100x and 1,000x magnification of $\mathrm{BD}-1 \mathrm{~B}$ at (a) $550^{\circ} \mathrm{C}$ and (b) $600^{\circ} \mathrm{C}$.

TABLE 7: XRD analysis of BD-1B ash.

\begin{tabular}{lccc}
\hline Temp. $\left({ }^{\circ} \mathrm{C}\right)$ & Compound name & $\begin{array}{c}\text { Chemical } \\
\text { formula }\end{array}$ & $\begin{array}{c}\text { SemiQuant } \\
(\%)\end{array}$ \\
\hline \multirow{2}{*}{550} & Silicon oxide & $\mathrm{SiO}_{2}$ & 93 \\
& Millosevichite & $\mathrm{Al}_{2} \mathrm{O}_{12} \mathrm{~S}_{3}$ & 7 \\
\hline \multirow{2}{*}{600} & Quartz high & $\mathrm{O}_{2} \mathrm{Si}_{1}$ & 13 \\
& Calcium sulfate & $\mathrm{Ca}\left(\mathrm{SO}_{4}\right)$ & 5 \\
& Iron oxide & $\mathrm{Fe}_{2} \mathrm{O}_{3}$ & 82 \\
\hline
\end{tabular}

of $1,530^{\circ} \mathrm{C}$. Problems arise if the other elements that melt first and bind $\mathrm{SiO}_{2}$ are heated continuously [22]. Another element with $7 \%$ is millosevichite $\left(\mathrm{Al}_{2} \mathrm{O}_{12} \mathrm{~S}_{3}\right)$ or $\mathrm{Al}_{2}\left(\mathrm{SO}_{4}\right)_{3}$. The possible reaction is that the element decomposes into $\mathrm{Al}_{2} \mathrm{O}_{3}$ and $\mathrm{Al}_{3} \mathrm{SO}_{3}$. The elemental base is $\mathrm{Al}_{2} \mathrm{O}_{3}$, so there is no need to be wary. The ash at $600^{\circ} \mathrm{C}$ is dominated by $\mathrm{F}_{2} \mathrm{O}_{3}$. It has started to transform at a temperature of around $590^{\circ} \mathrm{C}$ [21]; several other references mention around $800^{\circ} \mathrm{C}$.
Elements included in one clump are $\mathrm{FeO}, \mathrm{FeS}, \mathrm{Fe}_{2} \mathrm{O}_{3}$, and $\mathrm{Fe}_{2}\left(\mathrm{SO}_{4}\right)_{3}$, which may occur or be formed. $\mathrm{Fe}_{2} \mathrm{O}_{3}$ will melt completely at a temperature of around $1,500^{\circ} \mathrm{C}$. At this time, it can bind other elements. The element in the second position is $13 \%$ high quartz formed at a temperature of $570^{\circ} \mathrm{C}$ and has harmless properties as described at a probe temperature of $550^{\circ} \mathrm{C}$.

3.2.3. BD-2A Probe at $550^{\circ} \mathrm{C}$ and $600^{\circ} \mathrm{C}$. A probe at $550{ }^{\circ} \mathrm{C}$ with 100x magnification is morphologically dominated by material in the form of flakes measuring 100 microns and below that are coated with dust around them (see Figure 4). The main element is $\mathrm{Si}$, around $35 \%$ with a small amount of Al. There is $\mathrm{Fe}$ of $1.8 \%$. In a probe at $600^{\circ} \mathrm{C}$, the size of the flakes varies between 75 and 150 microns. In general, compared to the $550^{\circ} \mathrm{C}$ probes, this probe is cleaner than dust enveloping debris. Elements of $\mathrm{Si}$ are still very 

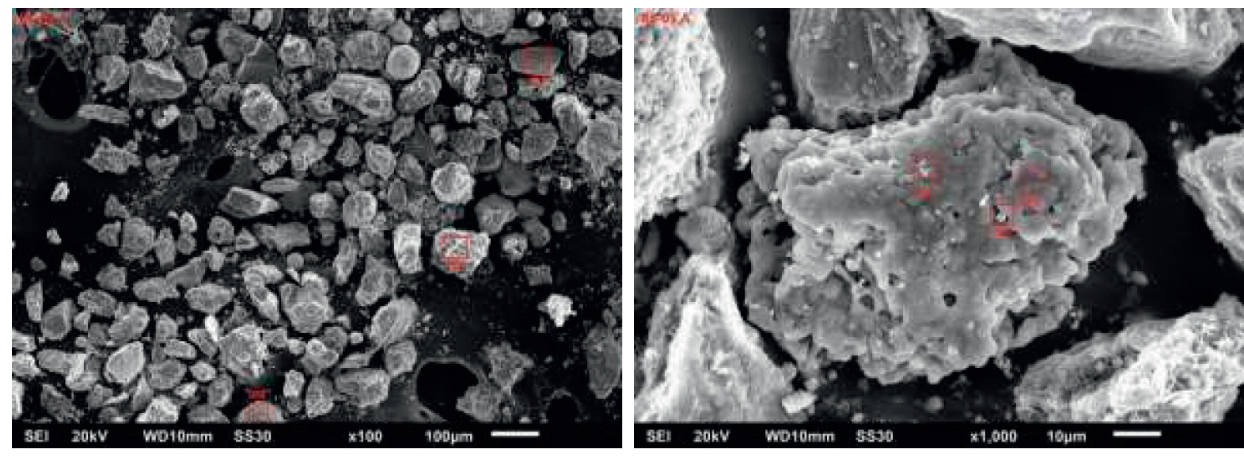

(a)
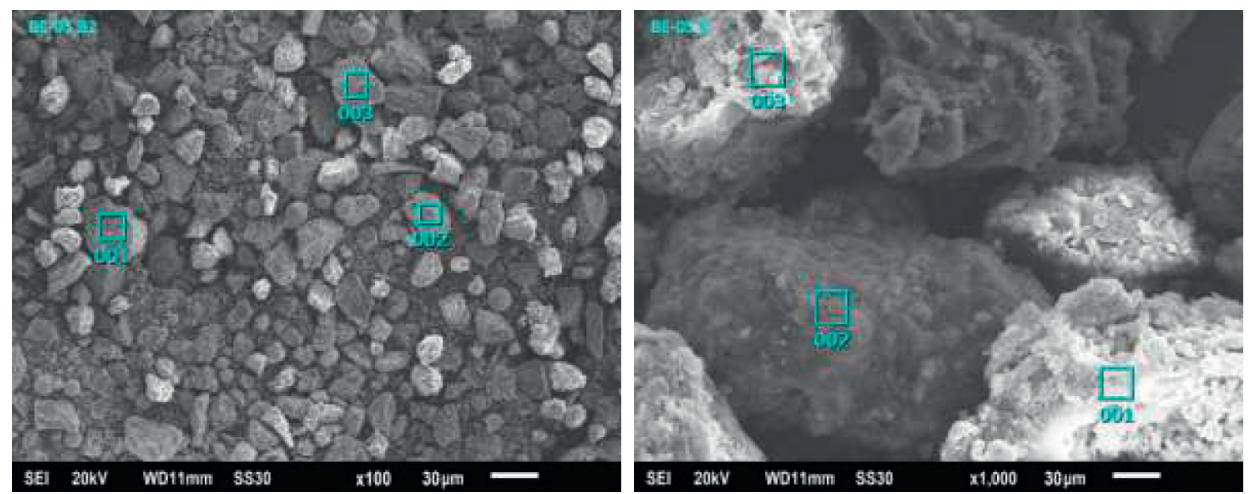

(b)

Figure 4: Comparison of $100 \mathrm{x}$ and $1,000 \mathrm{x}$ magnification of $\mathrm{BD}-2 \mathrm{~A}$ at (a) $550^{\circ} \mathrm{C}$ and (b) $600^{\circ} \mathrm{C}$.

dominant, and $\mathrm{Al}$ is not so large. There is about $1 \% \mathrm{Na}$. $\mathrm{K}$, $\mathrm{Ca}$, and $\mathrm{Fe}$ are in relatively low amounts.

Table 8 lists the result of the XRD analysis of BD-2A ash. At $550^{\circ} \mathrm{C}$, the probe is dominated by $95 \%$ quartz low, and in general, not dangerous. This number is medium and is a good trait. Another 5\% mineral is iron phosphate. Phosphate will melt at a temperature of around $48^{\circ} \mathrm{C}$, while Fe-phosphate melts at a temperature of $180^{\circ} \mathrm{C}$. This element needs to be aware of as a trigger for slagging because it has a lower melting temperature than $\mathrm{Fe}_{2} \mathrm{O}_{3}$, which begins to melt above $800^{\circ} \mathrm{C}$. At $600^{\circ} \mathrm{C}$, the probe is dominated by quartz low with $93 \%$. Another element is $7 \%$ millosevichite $\left(\mathrm{Al}_{2} \mathrm{O}_{12} \mathrm{~S}_{3}\right)$ or $\mathrm{Al}_{2}\left(\mathrm{SO}_{4}\right)_{3}$. The possible reaction is that the element decomposes into $\mathrm{Al}_{2} \mathrm{O}_{3}$ and $\mathrm{Al}_{3} \mathrm{SO}_{3}$.

3.2.4. BD-2B Probe at $550^{\circ} \mathrm{C}$ and $600^{\circ} \mathrm{C}$. A probe at $550^{\circ} \mathrm{C}$ with $100 \mathrm{x}$ magnification is morphologically dominated by $\mathrm{Si}$, as depicted in Figure 5. There are also $\mathrm{Al}$ and $\mathrm{Fe}$ with amounts below $6 \%$. The average flake size is about 100 microns or less. At 1,000x magnification, it can be seen in spots 1 and 2 that $\mathrm{Fe}$ content dominates with $50-60 \%$. Meanwhile, in spot 3, $\mathrm{Si}$ is more dominant with $19 \%$ compared to $\mathrm{Fe}$, which is only around $2 \%$. For the $600^{\circ} \mathrm{C}$ probe, the conditions were similar to that of the $550^{\circ} \mathrm{C}$ probe, where the predominance was flaked that were about 100 microns in size and slightly spherical (see Figure 5(b)). In this probe, the Fe content is relatively invisible. Si is still the dominant element at both $100 \mathrm{x}$ and $1,000 \mathrm{x}$ magnification.
The result of the XRD analysis of $\mathrm{BD}-2 \mathrm{~B}$ is summarized in Table 9. Based on XRD analysis, the probe at $550^{\circ} \mathrm{C}$ is dominated by high quartz with $82 \%$. Another element is $\mathrm{FeO}_{4} \mathrm{P}$ of $11 \%$, where this element begins to form at a temperature of around $590^{\circ} \mathrm{C}$. Another element is $\mathrm{FeO}_{4} \mathrm{P}$, which is still a group of iron. Fe-phosphate melts at a temperature of $180^{\circ} \mathrm{C}$, and one of the causes of slagging is its low melting temperature. Another element formed is $\mathrm{SO}_{2}$ by $7 \%$. On probe $600^{\circ} \mathrm{C}$, quart low dominates with $86 \%$ and indicates that the ash is harmless. Other elements are $\mathrm{Ca}_{3} \mathrm{Al}_{2} \mathrm{Si}_{2}$ by $10 \%$ and $\mathrm{FeO}_{4} \mathrm{P}$ by $4 \%$.

3.2.5. $B D-3 A$ Probe at $550^{\circ} \mathrm{C}$ and $600^{\circ} \mathrm{C}$. As seen in Figure $6(\mathrm{a})$, at the $550^{\circ} \mathrm{C}$ probe with $100 \mathrm{x}$ magnification, it appears that the ash is dominated by bright white flakes of about 100 microns. These bright white flakes indicate that there are elements of $\mathrm{Si}$ and $\mathrm{Al}$, which are quite dominating. There is also a grayish round shape that indicates the presence of Fe elements. No significant amount of melt is seen. At 1,000x magnification, spots 1 and 3 have $\mathrm{Si}$ and $\mathrm{Al}$ dominance. For spot 2, there is a large Fe. For the $600^{\circ} \mathrm{C}$ probe, as shown in Figure 6(b), the conditions were similar to the $550^{\circ} \mathrm{C}$ probe, where the predominance was flaked that were about 100 microns in size and slightly spherical, and there was no significant stickiness.

Probe at $550^{\circ} \mathrm{C}$ is dominated by silicon oxide $\left(\mathrm{SiO}_{2}\right) 84 \%$, where this element has a harmless character from its contribution to slagging and fouling and will even have a 
TABLE 8: XRD analysis of BD-2A ash.

\begin{tabular}{lccc}
\hline Temp. $\left({ }^{\circ} \mathrm{C}\right)$ & Compound name & Chemical formula & SemiQuant $(\%)$ \\
\hline \multirow{2}{*}{550} & Quartz low & $\mathrm{O}_{2} \mathrm{Si}_{1}$ & 95 \\
& Iron(III) phosphate(V)-beta & $\mathrm{Fe}_{1} \mathrm{O}_{4} \mathrm{P}_{1}$ & 5 \\
\hline \multirow{2}{*}{600} & Silicon oxide & $\mathrm{SiO}_{2}$ & 93 \\
& Millosevichite & $\mathrm{Al}_{2} \mathrm{O}_{12} \mathrm{~S}_{3}$ & 7 \\
\hline
\end{tabular}
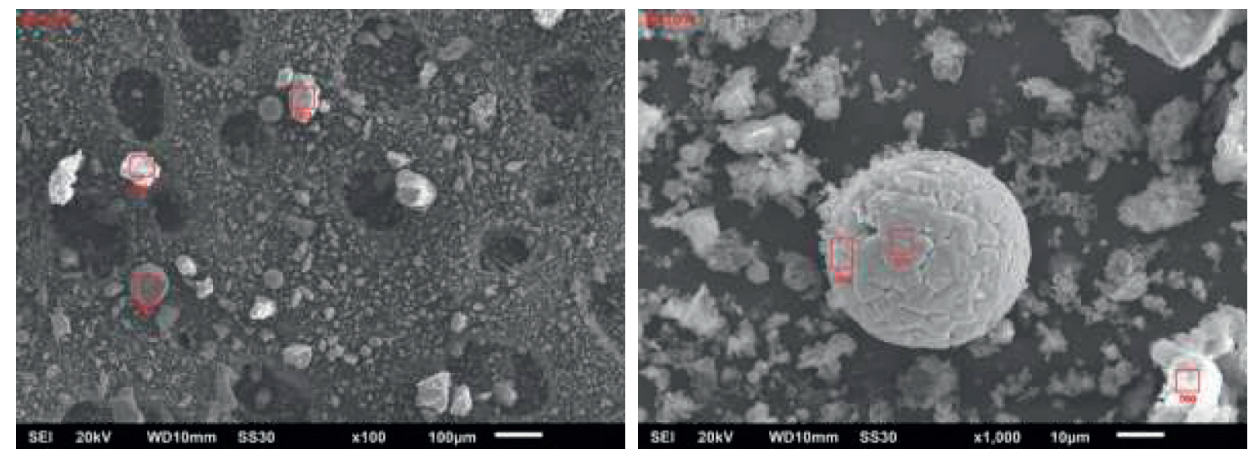

(a)
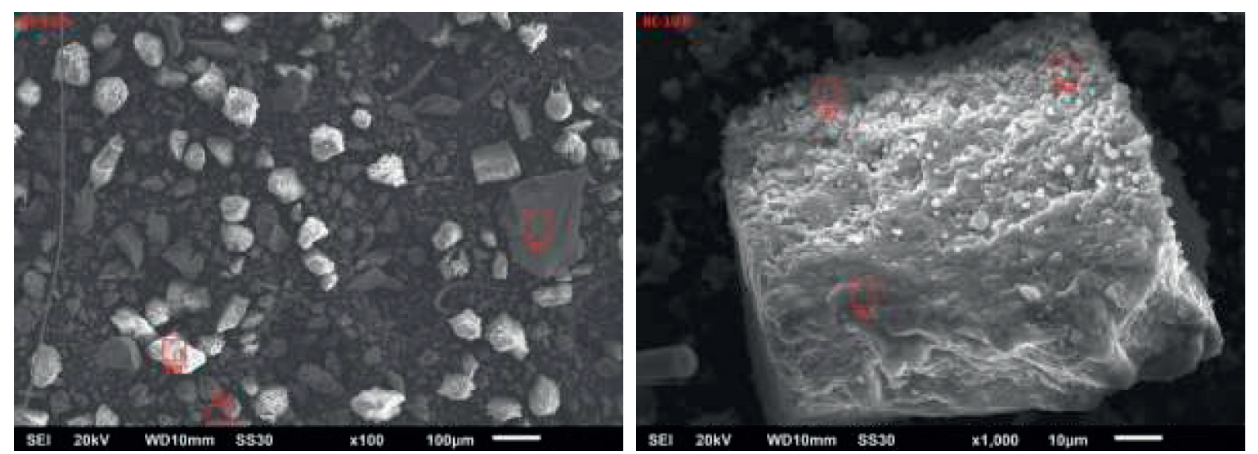

(b)

Figure 5: Comparison of $100 \mathrm{x}$ and 1,000x Magnification of $\mathrm{BD}-2 \mathrm{~B}$ at (a) $550^{\circ} \mathrm{C}$ and (b) $600^{\circ} \mathrm{C}$.

TABLE 9: XRD analysis of BD-2B ash.

\begin{tabular}{lccc}
\hline Temp. $\left({ }^{\circ} \mathrm{C}\right)$ & Compound name & Chemical formula & SemiQuant $(\%)$ \\
\hline \multirow{2}{*}{550} & Quartz high & $\mathrm{O}_{2} \mathrm{Si}_{1}$ & 82 \\
& Iron(III) phosphate(V)-alpha & $\mathrm{Fe}_{1} \mathrm{O}_{4} \mathrm{P}_{1}$ & 11 \\
\hline \multirow{2}{*}{600} & Sulfur(IV) oxide & $\mathrm{O}_{2} \mathrm{~S}_{1}$ & 7 \\
& Quartz low & $\mathrm{O}_{2} \mathrm{Si}_{1}$ & 86 \\
& Iron(III) phosphate(V)-beta & $\mathrm{Fe}_{1} \mathrm{O}_{4} \mathrm{P}_{1}$ & 4 \\
$\mathrm{Ca}_{3} \mathrm{Al}_{2} \mathrm{Si}_{2}$ & 10 \\
\hline
\end{tabular}

positive effect (see Table 10). This element will be stable up to a temperature of about $570^{\circ} \mathrm{C}$, where it will then be transformed into high quartz. At a temperature of $876^{\circ} \mathrm{C}$, it transforms into tridymite, and at a temperature of $1,400^{\circ} \mathrm{C}$, it transforms into cristobalite. Elemental quartz will be stable at a temperature of $1,530^{\circ} \mathrm{C}$. Problems arise if other elements melt first and bind $\mathrm{SiO}_{2}$ and then heat it continuously. The additional content is aluminum sulfate, as much as $16 \%$. In general, aluminum is a good influence on coal ash in terms of slagging but sulfate will have a negative effect. Similar to probe at $550^{\circ} \mathrm{C}$, at $600^{\circ} \mathrm{C}$, it is also dominated by silicon oxide $\left(\mathrm{SiO}_{2}\right)$ by $61 \%$. This element has a harmless character from its contribution to slagging and fouling and even has a positive effect.

3.2.6. $B D-3 B$ Probe at $550^{\circ} \mathrm{C}$ and $600^{\circ} \mathrm{C}$. Morphologically, the $550^{\circ} \mathrm{C}$ probe with $100 \mathrm{x}$ magnification is dominated by $\mathrm{Si}$ with a little Al. It can be seen in Figure 7(a). Flakes size varies. However, it is dominated by grain sizes of about 100 

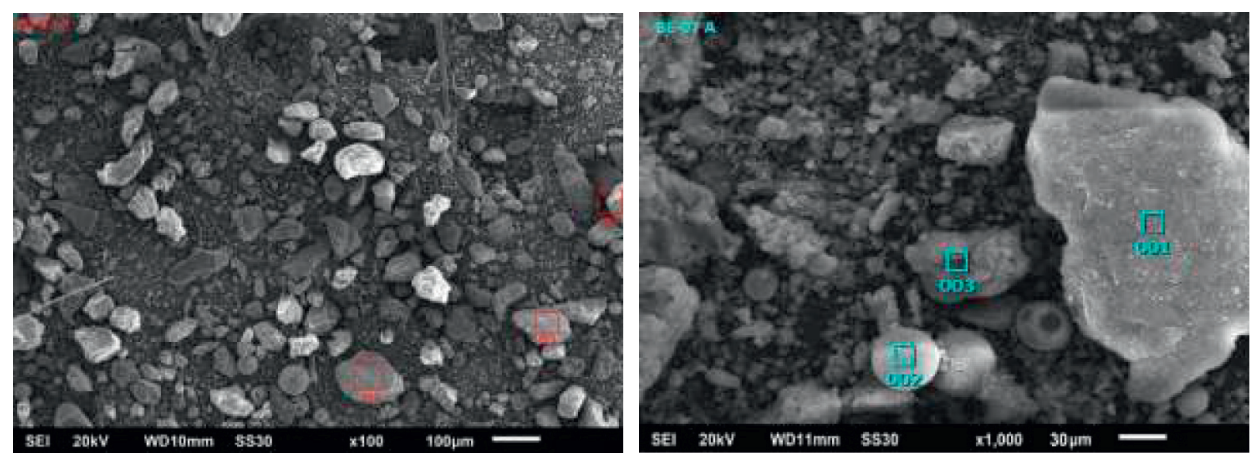

(a)
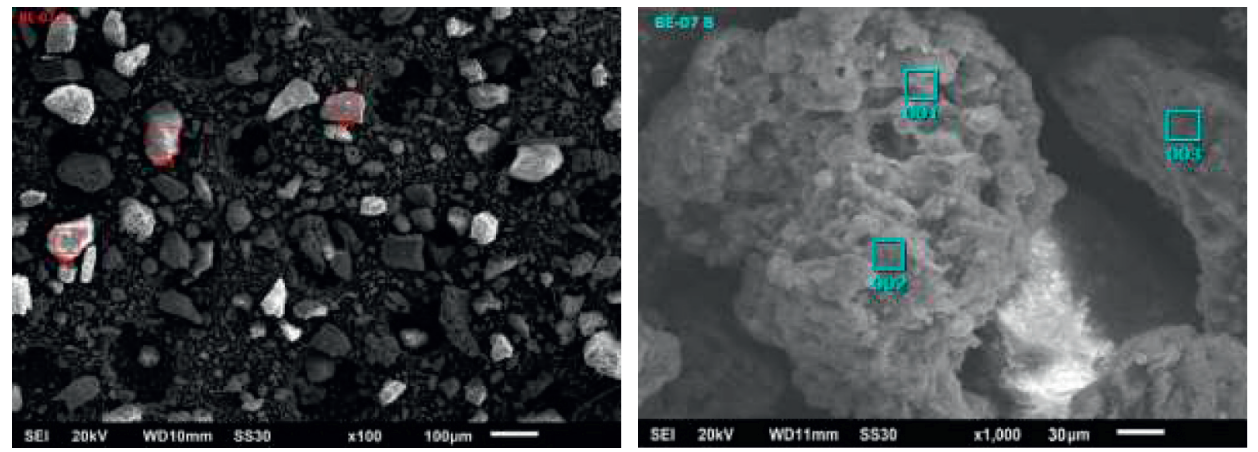

(b)

Figure 6: Comparison of 100x and 1,000x magnification of $\mathrm{BD}-3 \mathrm{~A}$ at (a) $550^{\circ} \mathrm{C}$ and (b) $600^{\circ} \mathrm{C}$.

TABLE 10: XRD analysis of BD-3A ash.

\begin{tabular}{lccc}
\hline Temp. $\left({ }^{\circ} \mathrm{C}\right)$ & Compound name & Chemical formula & SemiQuant $(\%)$ \\
\hline \multirow{2}{*}{550} & Silicon oxide & $\mathrm{SiO}_{2}$ & 84 \\
& Aluminum sulfate & $\mathrm{Al}_{2}\left(\mathrm{SO}_{4}\right)_{3}$ & 16 \\
\hline \multirow{2}{*}{600} & Silicon oxide & $\mathrm{SiO}_{2}$ & 61 \\
& Aluminum sulfate & $\mathrm{Al}_{2}\left(\mathrm{SO}_{4}\right)_{3}$ & 39 \\
\hline
\end{tabular}

microns or smaller. Magnification of 1,000x at spots 1,2, and 3 indicates that there is Si predominance, while other elements are minor. Figure 7(b) shows the morphology of BD$3 \mathrm{~B}$ at the $600^{\circ} \mathrm{C}$ probe with $100 \mathrm{x}$ magnification; Si and $\mathrm{Al}$ appear to be dominated by almost equal portions. At $1,000 \mathrm{x}$ spot magnification at spots 1,2 , and 3, there are other elements that dominate, namely, $\mathrm{Ca}$ and $\mathrm{S}$, while $\mathrm{Si}$ and $\mathrm{Al}$ are still present but in small amounts.

Based on the XRD analysis as listed in Table 11 , the $550^{\circ} \mathrm{C}$ probe is dominated by $89 \%$ quartz low. This element will be stable to a temperature of about $570^{\circ} \mathrm{C}$, and at a temperature of $876^{\circ} \mathrm{C}$, it will transform into tridymite and will be stable at a temperature of $1,530^{\circ} \mathrm{C}$. Another element is sulfuryl dichloride by $11 \%$. Quartz also dominates the $600^{\circ} \mathrm{C}$ probe by $63 \%$. The other element is anhydrite $\left(\mathrm{CaSO}_{4}\right)$ by $37 \%$. The reaction process occurs at temperatures between 800 and $1,000^{\circ} \mathrm{C}$ in the gas phase.

3.2.7. $\mathrm{BD}-4 \mathrm{~A}$ Probe at $550^{\circ} \mathrm{C}$ and $600^{\circ} \mathrm{C}$. Figures $8(\mathrm{a})$ and 8 (b) present the morphology of $\mathrm{BD}-4 \mathrm{~B}$ at the $550^{\circ} \mathrm{C}$ and $600^{\circ} \mathrm{C}$ probes. Morphologically, the $550^{\circ} \mathrm{C}$ probe with $100 \mathrm{x}$ magnification is dominated by debris below 100 microns in size. It is dominated by Si elements in all spots with a small amount of Al. At 1,000x magnification, the first spot is dominated by Mo, Ca, and $\mathrm{S}$ with a mass above $10 \%$. However, in spots 2 and 3, the Si element is still dominant at $40 \%$. Like the $550^{\circ} \mathrm{C}$ probe, at the $600^{\circ} \mathrm{C}$ probe, both at $100 \mathrm{x}$ and $1,000 \mathrm{x}$ magnification, the ash melt is dominated by $\mathrm{Si}$ (around $40 \%$ ) with a small amount of $\mathrm{Al}$.

In the XRD analysis, probe at $550^{\circ} \mathrm{C}$ is dominated by $70 \%$ quartz high, where this element positively affects slagging fouling (see Table 12). This element will be stable until about $570^{\circ} \mathrm{C}$, which will be transformed into quartz high. At a temperature of $876^{\circ} \mathrm{C}$, it transforms into tridymite, and at a temperature of $1,400^{\circ} \mathrm{C}$, it transforms into cristobalite. Elemental quartz will be stable at a temperature of $1,530^{\circ} \mathrm{C}$. Another element is aluminum sulfate by $30 \%$. Quartz also dominates the $600^{\circ} \mathrm{C}$ probe by $70 \%$. Another mineral is $20 \%$ calcium sulfate $\left(\mathrm{CaSO}_{4}\right)$. The reaction process occurs at temperatures between $800^{\circ} \mathrm{C}$ and $1,000^{\circ} \mathrm{C}$ in the gas phase. At $1,000^{\circ} \mathrm{C}-1,200^{\circ} \mathrm{C}, \mathrm{SO}_{4}$ is released and can react with other elements such as $\mathrm{Si}$ or $\mathrm{Al}$ to form $\mathrm{Ca}_{2} \mathrm{AlSiO}_{7}$. 

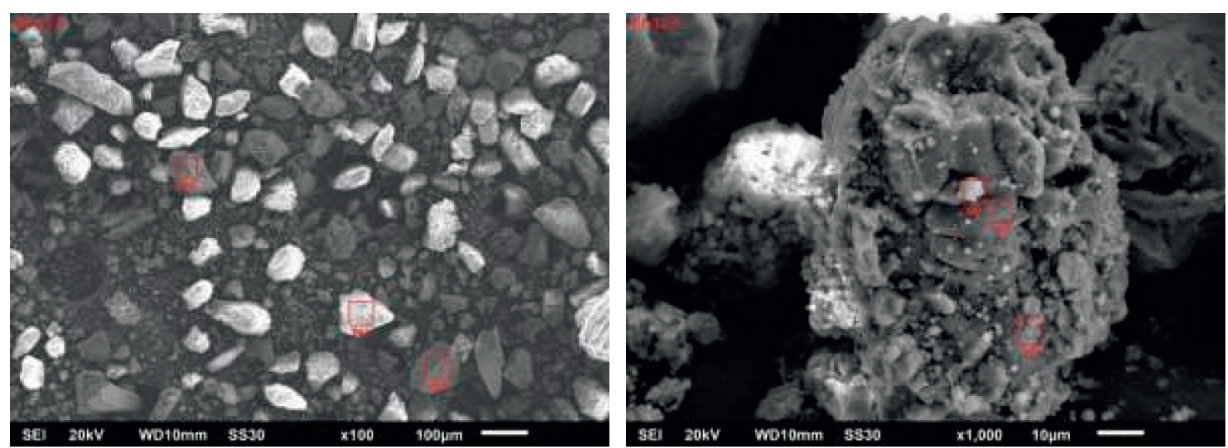

(a)
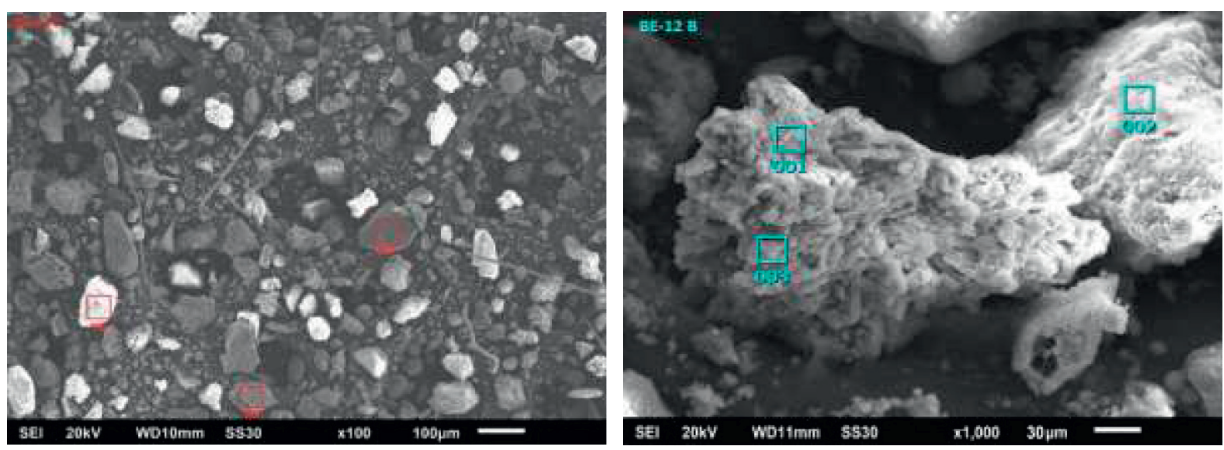

(b)

Figure 7: Comparison of 100x and 1,000x magnification of $\mathrm{BD}-3 \mathrm{~B}$ at (a) $550^{\circ} \mathrm{C}$ and (b) $600^{\circ} \mathrm{C}$.

TABLE 11: XRD analysis of BD-3B ash.

\begin{tabular}{lccc}
\hline Temp. $\left({ }^{\circ} \mathrm{C}\right)$ & Compound name & Chemical formula & SemiQuant $(\%)$ \\
\hline \multirow{2}{*}{550} & Quartz low & $\mathrm{O}_{2} \mathrm{Si}_{1}$ & 89 \\
& Sulfuryl dichloride & $\mathrm{Cl}_{2} \mathrm{O}_{2} \mathrm{~S}_{1}$ & 11 \\
\hline \multirow{2}{*}{600} & Quartz & $\mathrm{O}_{2} \mathrm{Si}_{1}$ & 63 \\
& Anhydrite & $\mathrm{Ca}_{1} \mathrm{O}_{4} \mathrm{~S}_{1}$ & 37 \\
\hline
\end{tabular}

3.2.8. $\mathrm{BD}-4 \mathrm{~B}$ Probe at $550^{\circ} \mathrm{C}$ and $600^{\circ} \mathrm{C}$. The $550^{\circ} \mathrm{C}$ probe is dominated dust in the form of flakes under 75 microns in size. Spot 1 is dominated by $29.66 \%$ Ca elements with very low $\mathrm{Si}$ and $\mathrm{Al}$ and $1.55 \% \mathrm{Fe}$ (see Figure 9(a)). Spot 2 is dominated by $\mathrm{Si} 26 \%$. Spot 3 is a round shape with the dominant element Fe $40.12 \%$. Meanwhile, the $600^{\circ} \mathrm{C}$ probe is dominated by flakes above 100 microns in size. There is no massive melt, but most particles are light white and dark gray flakes (see Figure 9(b)). But there are small balls scattered around. There is also a hollow lump, which indicates air in it. A solid but porous liquid form indicates this cavity. Spot 1 is dominated by $\mathrm{Si}$ and $\mathrm{Al}$. There are also K less than $1.22 \%$ and Fe $3.57 \%$. For spot 2, Fe is dominated by $58.36 \%$. At the same time, $\mathrm{Si}$ is only $8 \%$. Spot 3 is dominated by Si. From the appearance at $100 \mathrm{x}$ magnification, the typical material in spots 1 and 3 is more dominant than spot 2 (rich in $\mathrm{Fe}$ ). At 1,000x magnification, $\mathrm{Si}$ and $\mathrm{Al}$ are pretty high. There is a significant $\mathrm{Mg}$ that will have a good effect. But on the other hand, there is a relatively high $\mathrm{K}$ from $3.87 \%-7.14 \%$. Elemental $\mathrm{K}$ has a harmful impact because it will melt at low temperatures.

The result of the $\mathrm{XRD}$ analysis of $\mathrm{BD}-4 \mathrm{~B}$ is summarized in Table 13 . At $550^{\circ} \mathrm{C}$, the probe is dominated by quartz low that is $75 \%$ and is generally considered harmless. At the same time, another mineral is calcium sulfate $\left(\mathrm{CaSO}_{4}\right)$, as much as $19 \% . \mathrm{CaSO}_{4}$ that may occur is a reaction between $\mathrm{CaO}$ and $\mathrm{SO}_{2}$ or the elemental form of CaSO 4 from the beginning. The reaction process occurs at temperatures between $800^{\circ} \mathrm{C}$ and $1,000^{\circ} \mathrm{C}$ in the gas phase. At a temperature of $1,000^{\circ} \mathrm{C}$ $-1,200^{\circ} \mathrm{C}$ and above, $\mathrm{SO}_{4}$ is released and reacts with other elements such as $\mathrm{Si} / \mathrm{Al}$ forming $\mathrm{Ca}_{2} \mathrm{AlSiO}_{7}$. Besides, there is sulfur oxide in $6 \%$, which can react with $\mathrm{Ca}$ or $\mathrm{Na}$ at a temperature of around $1,000^{\circ} \mathrm{C}$ and form $\mathrm{Na}_{2} \mathrm{SO}_{4}$ or $\mathrm{CaSO}_{4}$. Same with $550^{\circ} \mathrm{C}$, at $600^{\circ} \mathrm{C}$ probe, is dominated by quartz low, which is $67 \%$. In contrast, the other minerals are calcium sulfate $\left(\mathrm{CaSO}_{4}\right)$ as much as $33 \%$. 

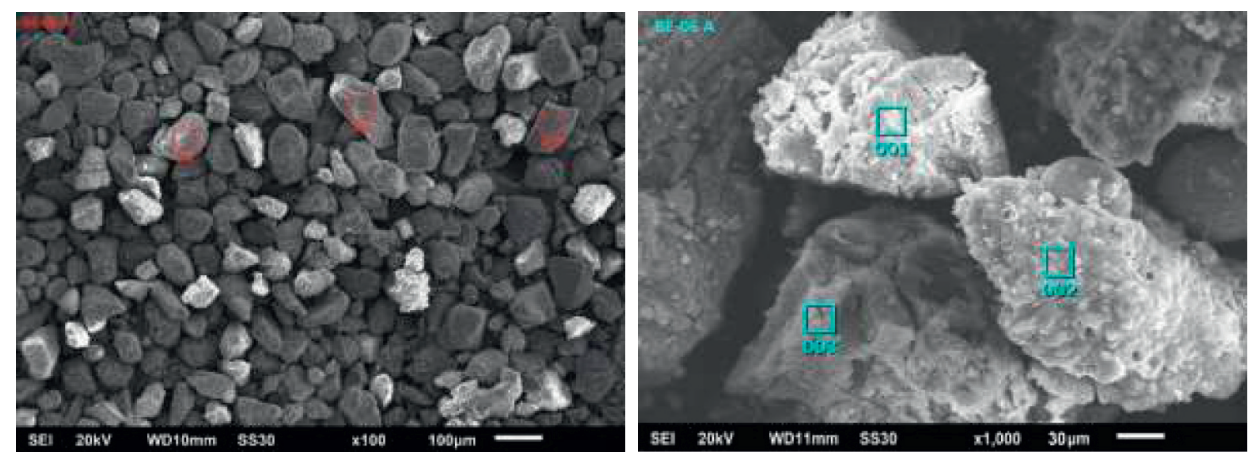

(a)
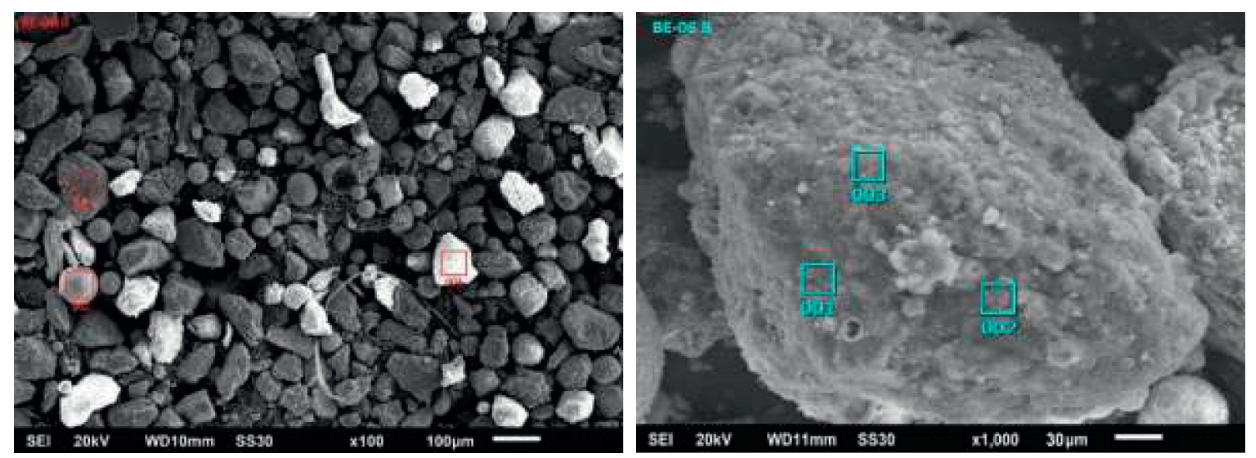

(b)

Figure 8: Comparison of 100x and 1,000x magnification of $\mathrm{BD}-4 \mathrm{~A}$ at (a) $550^{\circ} \mathrm{C}$ and (b) $600^{\circ} \mathrm{C}$.

TABLE 12: XRD analysis of BD-4A ash.

\begin{tabular}{lccc}
\hline Temp. $\left({ }^{\circ} \mathrm{C}\right)$ & Compound name & Chemical formula & SemiQuant (\%) \\
\hline \multirow{2}{*}{550} & Quartz high & $\mathrm{O}_{2} \mathrm{Si}_{1}$ & 70 \\
& Aluminum sulfate & $\mathrm{Al}_{2}\left(\mathrm{SO}_{4}\right)_{3}$ & 30 \\
\hline \multirow{2}{*}{600} & Quartz & $\mathrm{O}_{2} \mathrm{Si}_{1}$ & 78 \\
& Potassium iron (III) oxide & $\mathrm{Fe}_{1} \mathrm{~K}_{1} \mathrm{O}_{2}$ & 2 \\
& Calcium sulfate & $\left.\mathrm{Ca}_{2} \mathrm{SO}_{4}\right)$ & 20 \\
\hline
\end{tabular}
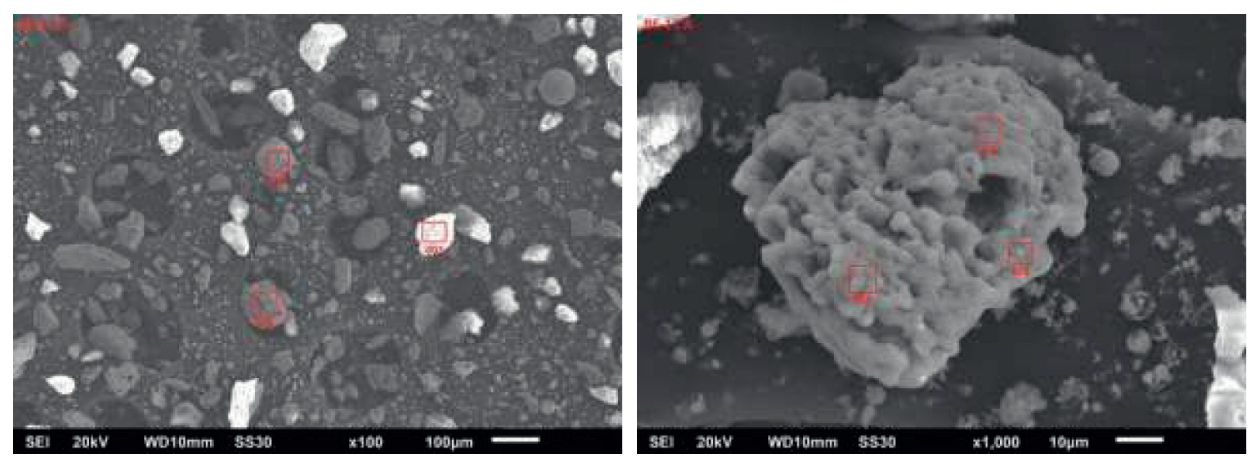

(a)

Figure 9: Continued. 

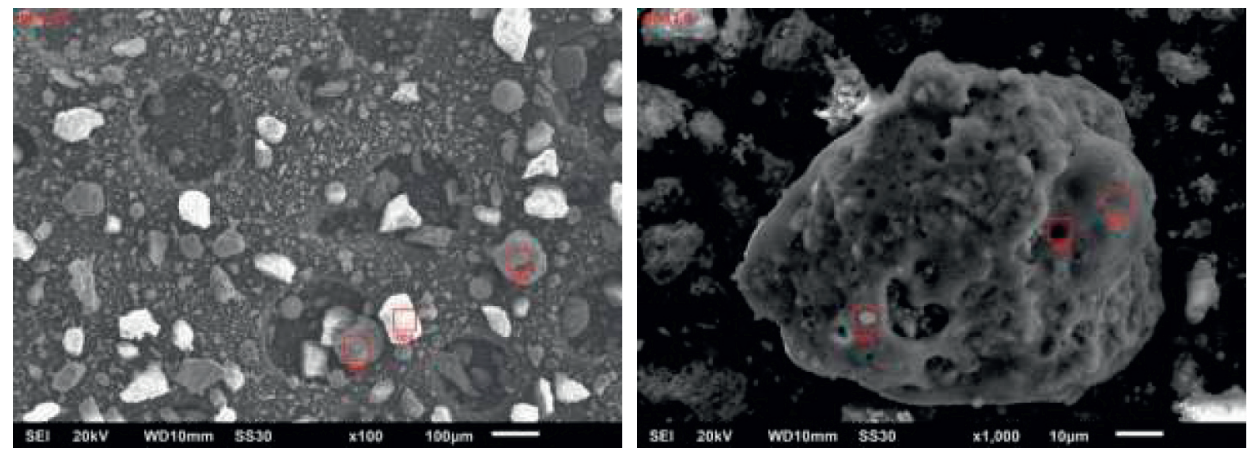

(b)

Figure 9: Comparison of 100x and 1,000x magnification of $\mathrm{BD}-4 \mathrm{~B}$ at (a) $550^{\circ} \mathrm{C}$ and (b) $600^{\circ} \mathrm{C}$.

TABLE 13: XRD analysis of BD-4B ash.

\begin{tabular}{lccc}
\hline Temp. $\left({ }^{\circ} \mathrm{C}\right)$ & Compound name & Chemical formula & SemiQuant $(\%)$ \\
\hline \multirow{2}{*}{550} & Quartz low & $\mathrm{O}_{2} \mathrm{Si}_{1}$ & 75 \\
& Sulfur oxide & $\mathrm{SO}_{2}$ & 6 \\
& Calcium sulfate & $\mathrm{Ca}_{2}\left(\mathrm{SO}_{4}\right)$ & 19 \\
\hline \multirow{2}{*}{600} & Quartz low & $\mathrm{O}_{2} \mathrm{Si}_{1}$ & 67 \\
& Anhydrite & $\mathrm{Ca}_{1} \mathrm{O}_{4} \mathrm{~S}_{1}$ & 33 \\
\hline
\end{tabular}

\section{Conclusion}

By combining the results of the ratios of ash components, observations of probes, SEM, and XRD test results, it was found that all the above combinations of coal mixtures can be used as fuel for coal power plants with the PC boiler type. Especially, the priority is aimed at BD-1B, namely, coal blending $\mathrm{KT} 50 \%$ and SS $50 \%$ plus additives and $\mathrm{BD}-4 \mathrm{~B}$ (50\% KT and 50\% KS coal blend with additive). It means that blending and additives are effective ways to overcome the potential for slagging and fouling.

\section{Data Availability}

The data used to support the findings of this study are included within the article. The comprehensive data used to support the findings of this study are also available from the corresponding author upon request.

\section{Conflicts of Interest}

The authors declare that they have no conflicts of interest.

\section{References}

[1] D. Arinaldo and J. C. Adiatma, Dinamika Batu Bara Indonesia, Institute for Essential Services Reform (IESR), Jakarta, Indonesia, 2019.

[2] T. F. Wall, S. P. Bhattacharya, D. K. Zhang, R. P. Gupta, and $\mathrm{X}$. He, "The properties and thermal effects of ash deposits in coal-fired furnaces," Progress in Energy and Combustion Science, vol. 19, no. 6, pp. 487-504, 1993.

[3] N. Hare, M. Rasul, and S. Moazzem, "A review on boiler deposition/foulage prevention and removal techniques for power plant," in Proceedings of the 5th IASME/WSEAS
International Conference on Energy \& Environment, Cambridge, UK, February 2010.

[4] H. B. Vuthaluru and D.-k. Zhang, "Effect of coal blending on particle agglomeration and defluidisation during spouted-bed combustion of low-rank coals," Fuel Processing Technology, vol. 70, no. 1, pp. 41-51, 2001.

[5] J. Li, M. Zhu, Z. Zhang, K. Zhang, G. Shen, and D. Zhang, "The mineralogy, morphology and sintering characteristics of ash deposits on a probe at different temperatures during combustion of blends of Zhundong lignite and a bituminous coal in a drop tube furnace," Fuel Processing Technology, vol. 149, pp. 176-186, 2016.

[6] J. Li, M. Zhu, Z. Zhang, K. Zhang, G. Shen, and D. Zhang, "Effect of coal blending and ashing temperature on ash sintering and fusion characteristics during combustion of Zhundong lignite," Fuel, vol. 195, pp. 131-142, 2017.

[7] B. Wei, H. Tan, X. Wang, R. Ruan, Z. Hu, and Y. Wang, "Investigation on ash deposition characteristics during Zhundong coal combustion," Journal of the Energy Institute, vol. 91, no. 1, pp. 33-42, 2018.

[8] P. Plaza, The Development of a Slagging and Fouling Predictive Methodology for Large Scale Pulverised Boilers Fired Withcoal/ biomass Blends, Cardiff University, Cardiff, UK, 2013.

[9] H. Y. Park, J. E. Lee, H. H. Kim et al., "Thermal resistance by slagging and its relationship with ash properties for six coal blends in a commercial coal-fired boiler," Fuel, vol. 235, pp. 1377-1386, 2019.

[10] M. Z. S. M. Zaid, M. A. Wahid, M. Mailah, M. A. Mazlan, and A. Saat, "Coal fired power plant: a review on coal blending and emission issues," AIP Conf. Proc.American Institute of Physics Inc., vol. 2062, p. 30015, College Park, MD, USA, 2019.

[11] A. J. Lowe, D. J. A. McCaffrey, and D. G. Richards, "An investigation into the effectiveness of fireside fuel additives," Fuel Processing Technology, vol. 36, no. 1-3, pp. 47-53, 1993.

[12] L. Zhao, H. Tran, and F. D. Mccabe, "Effectiveness of magnesium oxide additives in mitigating fouling problems in $\mathrm{kraft}$ recovery boilers," June 2013, vol. 12, no. 6, pp. 19-27, 2013. 
[13] L. Wang, J. E. Hustad, Ø. Skreiberg, G. Skjevrak, and M. Grønli, "A critical review on additives to reduce ash related operation problems in biomass combustion applications," Energy Procedia, vol. 20, pp. 20-29, 2012.

[14] V. Benavente and A. Fullana, "Low-cost additives to improve the fusion behaviour of hydrochar ash," Fuel, vol. 285, Article ID 119009, 2021.

[15] Y. Fan, Q. Lyu, Z. Zhu, and H. Zhang, "The impact of additives upon the slagging and fouling during Zhundong coal gasification," Journal of the Energy Institute, vol. 93, no. 4, pp. 1651-1665, 2020.

[16] Z. Ma, F. Iman, P. Lu et al., "A comprehensive slagging and fouling prediction tool for coal-fired boilers and its validation/ application," Fuel Processing Technology, vol. 88, no. 11-12, pp. 1035-1043, 2007.

[17] F. Frandsen, Empirical Prediction of Ash Deposition Propensities in Coal-Fired Utilities, Technical University of Denmark, Lyngby, Denmark, 1997.

[18] B. C. Winegartner, Coal Fouling and Slagging Parameters, ASME (Book H-86), New York, NY, USA, 1974.

[19] C. López, S. Unterberger, J. Maier, and K. R. G. Hein, "Overview of actual methods for characterization of ash depostion," Refereed Proceedings, 2003.

[20] X. Qi, G. Song, W. Song, S. Yang, and Q. Lu, "Effects of wall temperature on slagging and ash deposition of Zhundong coal during circulating fluidized bed gasification," Applied Thermal Engineering, vol. 106, pp. 1127-1135, 2016.

[21] R. W. Bryers, "Fireside slagging, fouling, and high-temperature corrosion of heat-transfer surface due to impurities in steam-raising fuels," Progress in Energy and Combustion Science, vol. 22, no. 1, pp. 29-120, 1996.

[22] A. P. Reifenstein, H. Kahraman, C. D. A. Coin, N. J. Calos, G. Miller, and P. Uwins, "Behaviour of selected minerals in an improved ash fusion test: quartz, potassium feldspar, sodium feldspar, kaolinite, illite, calcite, dolomite, siderite, pyrite and apatite," Fuel, vol. 78, no. 12, pp. 1449-1461, 1999.

[23] J. L. Míguez, J. Porteiro, F. Behrendt, D. Blanco, D. Patino, and A. Dieguez-Alonso, "Review of the use of additives to mitigate operational problems associated with the combustion of biomass with high content in ash-forming species," Renewable and Sustainable Energy Reviews, vol. 141, Article ID 110502, 2021.

[24] R. Weber, Y. Poyraz, M. Mancini, and A. Schwabauer, "Biomass fly-ash deposition: dependence of deposition rate on probe/particle temperature in $115-1200{ }^{\circ} \mathrm{C}$ range," Fuel, vol. 290, Article ID 120033, 2021. 